\title{
Relationship of circulating insulin-like growth factor-I and binding proteins 1-7 with mammographic density among women undergoing image-guided diagnostic breast biopsy
}

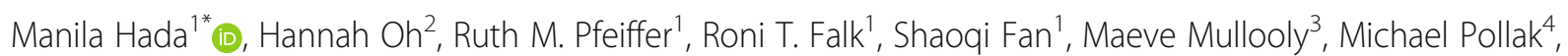
Berta Geller', Pamela M. Vacek ${ }^{5}$, Donald Weaver ${ }^{5}$, John Shepherd ${ }^{6}$, Jeff Wang ${ }^{7}$, Bo Fan ${ }^{8}$,

Amir Pasha Mahmoudzadeh" ${ }^{8}$, Serghei Malkov ${ }^{8}$, Sally Herschorn ${ }^{5}$, Louise A. Brinton ${ }^{1}$, Mark E. Sherman ${ }^{9}$ and Gretchen L. Gierach ${ }^{1}$

\begin{abstract}
Background: Mammographic density (MD) is a strong breast cancer risk factor that reflects fibroglandular and adipose tissue composition, but its biologic underpinnings are poorly understood. Insulin-like growth factor binding proteins (IGFBPs) are markers that may be associated with MD given their hypothesized role in breast carcinogenesis. IGFBPs sequester IGF-I, limiting its bioavailability. Prior studies have found positive associations between circulating IGF-I and the IGF-I:IGFBP-3 ratio and breast cancer risk. We evaluated the associations of IGF-I, IGFBP-3, and six other IGFBPs with MD.

Methods: Serum IGF measures were quantified in 296 women, ages 40-65, undergoing diagnostic image-guided breast biopsy. Volumetric density measures (MD-V) were assessed in pre-biopsy digital mammograms using single $X$-ray absorptiometry. Area density measures (MD-A) were estimated by computer-assisted thresholding software. Age, body mass index (BMI), and $\mathrm{BMI}^{2}$-adjusted linear regression models were used to examine associations of serum IGF measures with MD. Effect modification by BMI was also assessed.

Results: IGF-I and IGFBP-3 were not strongly associated with MD after BMI adjustment. In multivariable analyses among premenopausal women, IGFBP-2 was positively associated with both percent MD-V $(\beta=1.49, p$ value $=0.02)$ and MD-A ( $\beta=1.55, p$ value $=0.05)$. Among postmenopausal women, positive relationships between IGFBP-2 and percent MD-V $(\beta=2.04, p=0.003)$ were observed; the positive associations between IGFBP-2 and percent MD-V were stronger among lean women $\left(\mathrm{BMl}<25 \mathrm{~kg} / \mathrm{m}^{2}\right)(\beta=5.32, p=0.0002 ; p$ interaction $=0.0003)$.

Conclusions: In this comprehensive study of IGFBPs and MD, we observed a novel positive association between IGFBP-2 and MD, particularly among women with lower BMI. In concert with in vitro studies suggesting a dual role of IGFBP-2 on breast tissue, promoting cell proliferation as well as inhibiting tumorigenesis, our findings suggest that further studies assessing the role of IGFBP-2 in breast tissue composition, in addition to IGF-1 and IGFBP-3, are warranted.
\end{abstract}

Keywords: Mammographic density, Breast density, Insulin-like growth factor, Insulin-like growth factor binding proteins, Breast neoplasm

\footnotetext{
* Correspondence: manila.hada@nih.gov

${ }^{1}$ National Cancer Institute, National Institutes of Health, Bethesda, MD, USA

Full list of author information is available at the end of the article
}

(c) The Author(s). 2019 Open Access This article is distributed under the terms of the Creative Commons Attribution 4.0 International License (http://creativecommons.org/licenses/by/4.0/), which permits unrestricted use, distribution, and

reproduction in any medium, provided you give appropriate credit to the original author(s) and the source, provide a link to the Creative Commons license, and indicate if changes were made. The Creative Commons Public Domain Dedication waiver (http://creativecommons.org/publicdomain/zero/1.0/) applies to the data made available in this article, unless otherwise stated. 


\section{Background}

Increased mammographic breast density (MD) is an established risk factor for breast cancer [1, 2], which reflects the relative proportions of fibroglandular and adipose tissue content within the breast [3, 4]. However, most women with high MD neither have prevalent tumor nor will develop one in future. The determinants of MD and the mechanisms by which it increases the risk of breast cancer are poorly understood. Identifying factors associated with MD could elucidate the mechanisms by which breast density contributes to the risk of breast cancer and may improve risk prediction. Several lines of evidence have demonstrated the role of the insulin-like growth factor (IGF) system in breast cancer as either a tumor suppressor or promoter [5-7]. IGF proteins may be an underlying link between MD and the risk of breast cancer.

The insulin-like growth factor (IGF) system comprises transmembrane growth factor receptors, growth factor ligands (IGFs), IGF binding proteins (IGFBPs), proteases, and IGFBP-related proteins (IGFBP-rP) [8-10] (Fig. 1). IGF-I is produced by the liver in response to growth hormone produced by the pituitary gland. Bioavailability of IGF-I is regulated by numerous IGFBPs. IGFBPs have high affinity to IGFs and modulate their access to IGF receptors. IGF proteases dissociate the IGFBP-IGF complex and the freed IGFs can then bind to the IGF receptors, activating downstream signaling pathways: the phosphatidylinositol-3-kinase and RAS-extracellular signal-regulated kinase pathways [11]. Activation of these tyrosine kinase pathways plays a significant role in cell proliferation, differentiation, and metabolism. Indeed, dysregulated IGF-axis proteins have been shown to play a critical role in carcinogenesis of several human cancers including breast cancer [12].
Laboratory studies suggest that IGF-I may promote breast tumorigenesis by stimulating cell proliferation and inhibiting apoptosis $[10,13]$. A pooled analysis of 17 prospective epidemiologic studies showed that circulating IGF-I was associated with a $25 \%$ increased risk of breast cancer comparing women from the highest quintile to the lowest quintile, and this association did not vary by menopausal status [14]. Higher circulating concentrations of IGF-I as well as the ratio of IGF-I:IGFBP3 have been shown to be associated with higher MD in premenopausal women in some studies [15-18], whereas others have not observed an association [16, 19-22]. Among postmenopausal women, there is little evidence for a relationship between IGF-I, IGF-I:IGFBP-3, and MD [16-19, 21-24].

While prior studies have largely focused on the role of IGF-I, IGFBP-3, and the ratio of IGF-I:IGFBP-3 in MD, the relationship of other IGFBPs (IGFBP-1, 2, 4, 5, 6, and 7 and their ratio to IGF-I) with MD has not been elucidated. Epidemiological studies have not extensively explored the associations of other IGFBPs (IGFBP 4, 5, 6 , and 7) and breast cancer risk, with the exception of IGFBP-2, where findings have been inconsistent [25-27]. Laboratory and clinical data also suggest a role for IGFBPs in mammary gland development and breast carcinogenesis [28-34]. Although IGFBPs have significant sequence homology, they have different structures, binding patterns, and affinities [35]. IGFBPs are also known to exert IGF-dependent and independent actions [36, 37], with distinct functions in the breast [38]. Thus, in order to fully understand the role of the IGF system in MD, a panel of IGBPs may need to be investigated. We therefore assessed the relationship between serum levels of IGF-I and seven of its binding proteins with area and volume

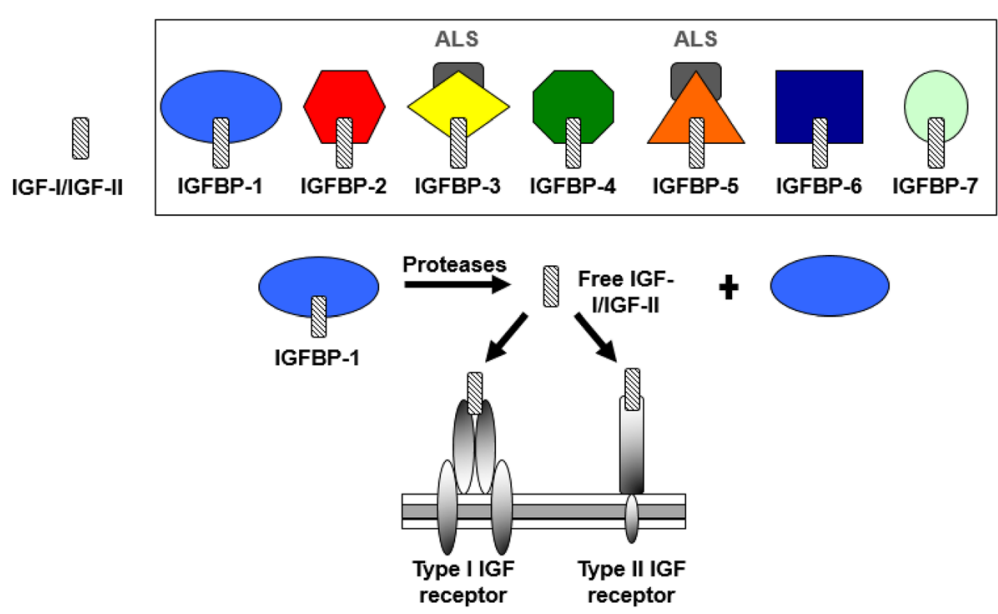

Fig. 1 Schematic representation of the insulin-like growth factor (IGF) system. The IGF system consists of IGF-I and IGF-II, IGF binding proteins (IGFBP-1 to7), and type I and II IGF receptors. IGFBPs have high affinity to IGFs and modulate their access to IGF receptors. IGF proteases dissociate the IGFBP-IGF complex, and the freed IGFs can then bind to the IGF receptors, activating downstream signaling pathways: the phosphatidylinositol-3-kinase and RAS-extracellular signal-regulated kinase pathways. ALS: Acid Labile Subunit 
measures of MD in a cross-sectional study of women referred for image-guided diagnostic breast biopsy.

\section{Methods \\ Study population}

The National Cancer Institute (NCI) Breast Radiology Evaluation and Study of Tissues (BREAST) Stamp Project is a cross-sectional study of MD conducted among 465 women, aged 40 to 65 years, who were referred for diagnostic image-guided breast biopsy based on an abnormal mammogram from 2007 through 2010 at the University of Vermont (UVM) College of Medicine and University of Vermont Medical Center as described previously [39]. Participants had no prior history of breast cancer or receiving cancer treatment, had not undergone breast surgery within 1 year, did not have breast implants, and were not taking breast cancer chemoprevention [39]. A standard self-administered questionnaire collected information on participants' health history.

Out of 465 women who consented to participate in the study, at least 1 vial of serum was collected from 346 (74\%) women. Of these 346 women, 21 with missing mammographic density data and 29 who were current hormone users (menopausal hormone therapy/oral contraceptives) were excluded from the study. This resulted in a population of 296 women (193 premenopausal and 103 postmenopausal) eligible for serum IGF and IGFBP protein measurement.

\section{Mammographic density assessment}

Digital raw mammogram images were sent to the University of California at San Francisco (UCSF) for quantitative volumetric and area density assessment [39]. This analysis was restricted to prebiopsy craniocaudal views of the ipsilateral breast. The mammogram closest in time prior to breast biopsy date was selected for this analysis. Area measures of density (MD-A) were estimated by an experienced trained reader with demonstrated reliability [40, 41] using UCSF's computer-assisted thresholding software which is comparable to other validated methods [40, 42]. Absolute dense area $\left(\mathrm{cm}^{2}\right)$ was measured by setting a pixel threshold for dense tissue. Percentage MD was calculated by dividing absolute dense breast area by total breast area and multiplying by 100 . Single X-ray absorptiometry (SXA), in which a density phantom was affixed to the mammographic compression paddle and included in the $\mathrm{X}$-ray field, was used to estimate breast density as an absolute and percent fibroglandular volume (MD-V) $\left(\mathrm{cm}^{3}\right)$ as described previously [43]. Previous reproducibility of SXA MD measures demonstrated a repeatability SD of $2 \%$, with a $2 \%$ accuracy for the entire thickness and density ranges [43]. The mean difference in time between age at biopsy and age at mammogram was 0.048 year; thus, on average, there was less than 6 months between age at biopsy and mammogram.

\section{Blood collection and laboratory assay}

Whole blood samples were collected using standard techniques, allowed to clot for $30 \mathrm{~min}$, and processed at the UVM General Clinical Research Center. Samples were centrifuged at $3000 \mathrm{rpm}$ for $15 \mathrm{~min}$, and serum was aliquoted into $2.0-\mathrm{mL}$ cryovials and frozen at $-80^{\circ} \mathrm{C}$ until shipment to the $\mathrm{NCI}$ biorepository, where vials are stored in liquid nitrogen. Serum concentrations $(\mathrm{ng} / \mathrm{mL})$ of IGF-I, IGFBP-1, IGFBP-2 and IGFBP-3 were measured as previously described [44-46]. IGF-I and IGFBP3 were measured using chemiluminescence immunoassay (CLIA) from Immunodiagnostic Systems Ltd. (Boldon, UK). IGFBP-1, 2, 4, 5, 6, and 7 were measured by enzyme-linked immunosorbent assay using reagents from ALPCO (Salem, $\mathrm{NH}$ ), Ansh Labs LLC (Webster, TX), Raybiotech Inc. (Norcross, GA), and R\&D Systems Inc. (Minneapolis, MN). Measurement of these proteins required $400 \mu \mathrm{l}$ of serum from each participant for duplicate measurements for each assay. The average of the duplicate measurements was used as the summary measure in the analysis. To monitor the assay reliability, 32 masked quality control samples (10\% of total samples) were included within and across batches. Within batch and between batches' coefficients of variation (CV) for IGF-I and IGFBP-1-7 were all < $8 \%$ and intraclass correlations (ICC) for all were above $92 \%$ (Table 1 ).

\section{Statistical analysis}

Analyses were conducted for women overall and stratified by menopausal status as the level of several IGF and MD measures differed by menopausal status. Median and 10th and 90th percentiles of analyte concentrations were calculated using untransformed IGF measures. For IGFBP-1, 91 samples were below the lower limit of detection (LLOD) and were reassigned as $1 / 2$ of LLOD $(0.025 \mathrm{ng} / \mathrm{ml})$.

To study the relationship between IGF measures and participant characteristics, IGF measures were logarithmically transformed to normalize the distributions, and geometric mean IGF concentrations and $95 \%$ confidence intervals were estimated in the analysis of variance (ANOVA) models. The characteristics examined were age at biopsy (premenopausal $<45,45-49, \geq 50$ years; postmenopausal $<54,55-59, \geq 60$ years), education ( $\leq$ high school graduate or GED; some college/technical school; college or post-college graduate), body mass index (BMI) $\left(<25,25-29.9, \geq 30 \mathrm{~kg} / \mathrm{m}^{2}\right)$, age at menarche $(\leq 12,13, \geq$ 14 years), age at first birth (nulliparous/30+ years, $<30$ years), oral contraceptive use (never, former), menopausal hormone therapy use (never, former), family history of breast cancer in a first-degree relative (none, 1, or more), 
Table 1 Distribution of circulating IGF-I and IGFBPs 1-7 (ng/ml) among BREAST Stamp Project participants, stratified by menopausal status

\begin{tabular}{|c|c|c|c|c|c|c|c|c|}
\hline \multirow{2}{*}{$\begin{array}{l}\text { IGF } \\
\text { measure }\end{array}$} & \multicolumn{2}{|c|}{ QC measures } & \multicolumn{3}{|c|}{ Premenopausal $(N=193)$} & \multicolumn{3}{|c|}{ Postmenopausal $(N=103)$} \\
\hline & $\overline{C V}(\%)$ & ICC (\%) & Median $^{1}$ & 10th percentile & 90th percentile & Median & 10th percentile & 90th percentile \\
\hline |GF-| & 2.03 & 99.6 & 120 & 83.7 & 182 & 111 & 72.5 & 143 \\
\hline IGFBP-1 $\left.\right|^{2}$ & 7.50 & 99.0 & 2.05 & 0.03 & 6.39 & 1.86 & 0.03 & 7.31 \\
\hline IGFBP-2 & 3.75 & 99.4 & 341 & 177 & 639 & 357 & 149 & 616 \\
\hline IGFBP-3 & 6.19 & 92.2 & 3502 & 2715 & 4455 & 3519 & 2676 & 4508 \\
\hline IGFBP-4 & 5.70 & 95.3 & 130 & 99 & 176 & 156 & 117 & 218 \\
\hline IGFBP-5 & 5.32 & 96.1 & 387 & 280 & 508 & 402 & 291 & 521 \\
\hline IGFBP-6 & 5.45 & 94.2 & 188 & 143 & 240 & 176 & 128 & 238 \\
\hline |GFBP-7 & 5.43 & 92.2 & 105 & 86.2 & 134 & 115 & 99.1 & 139 \\
\hline
\end{tabular}

CV coefficient of variation, ICC intraclass correlation coefficient, IGF insulin-like growth factor, IGFBP IGF binding protein

${ }^{1}$ Median and 10 and 90 th percentiles were calculated using untransformed IGF measures

${ }^{2}$ For IGFBP-1, N = 91 samples were below the lower limit of detection (LLOD) and were reassigned as $1 / 2$ LLOD (0.025)

age at menopause $(<45,45-49, \geq 50$ years $)$, cigarette smoking (never, former, current), breast biopsy prior to enrollment (never, ever), and biopsy diagnosis (benign non-proliferative, proliferative with/without atypia, in situ/invasive). Trends across categories of reproductive and other risk factors were calculated by treating the categories as ordinal variables. Heterogeneity between categories was assessed by $F$ tests arising from the ANOVA. The participant characteristics that were evaluated as confounders were associated with both the IGF and MD measures. Age, BMI, and cigarette smoking were previously identified as being associated with MD [39], and as they were also associated with IGF measures, we considered these factors as potential confounders.

Initially, age and categorical BMI-adjusted linear regression models were used to examine associations of serum IGF measures with measures of MD-A, MD-V, non-dense volume, and non-dense area as the dependent variables (Additional file 1: Tables S4, S5, and S7). To better capture potential confounding by BMI, we added a quadratic term for BMI, resulting in a final multivariate linear regression model adjusting for age, $\mathrm{BMI}$, and $\mathrm{BMI}^{2}$; for these analyses, 4 pre- and 2 postmenopausal women with BMI $>45 \mathrm{~kg} / \mathrm{m}^{2}$ were excluded, resulting in a final analytic population of 189 pre- and 101 postmenopausal women. MD measures were square-root transformed to normalize the distributions. Adjustment for cigarette smoking did not substantially change the estimates, and, as such, smoking was not included in the final models. We examined individual IGF measures, the ratio of IGF-I and individual IGFBPs, and the ratio of IGF-I and total IGFBPs (sum of molar concentration of individual IGFBPs). In sensitivity analyses, we examined the relation between serum IGF measures and MD after excluding women whose biopsy diagnosis included in situ or invasive breast carcinoma $(N=51)$. Effect modification by BMI was also assessed.
Factor analysis was used to evaluate the covariation among IGF measures in pre- and postmenopausal women (PROC FACTOR, SAS Institute INC., Cary $\mathrm{NC}$ ). Factor analysis allows one to represent covariance relationships contained in several, correlated variables (e.g., IGF measures) in terms of a few (unobserved) factors [47]. To obtain the factors, we repartitioned the shared variance and the unique variance for each observed variable into linear combinations (principal components) and used Kaiser's rule [48] to decide how many factors to retain in the model. For ease of interpretation, we derived uncorrelated factors through rotation. Factor scores were calculated for each woman and used in quintiles in linear regression to estimate the association between the factor and MD measures. We estimated factors using data from all women; however, basic patterns did not change when factors were computed separately for pre- and postmenopausal women.

All statistical tests were two-sided with probability values of $<0.05$ considered to be statistically significant. All the analyses were conducted with SAS software, version 9.4 (SAS Institute INC., Cary, NC).

\section{Results \\ Participant characteristics}

Overall, $94 \%$ of subjects were white and $65 \%(N=193)$ of the study participants were premenopausal (Additional file 1: Table S1). Among premenopausal women, $50.3 \%$ had BMI $<25 \mathrm{~kg} / \mathrm{m}^{2}$, and among postmenopausal women, $39.8 \%$ had BMI $<25 \mathrm{~kg} / \mathrm{m}^{2}$. The majority of pre- $(51 \%)$ and postmenopausal (64.1\%) women had age at first birth $<30$ years, and $23.3 \%$ of pre- and $21.4 \%$ of postmenopausal women were nulliparous. Most pre- $(88.5 \%)$ and postmenopausal (65\%) women had never used menopausal hormone therapy (Additional file 1: Table S1). 


\section{Distribution of IGF and IGFBPs in women stratified by menopausal status}

The correlations between the IGF measures are presented in Additional file 1: Table S2. Distributions of the IGF measures are reported in Table 1. In both pre- and postmenopausal women, IGFBP-1 had the lowest serum concentration and IGFBP-3 had the highest serum concentration (Table 1). Median circulating levels of IGF-I were significantly higher in premenopausal $(120 \mathrm{ng} / \mathrm{ml})$ compared with postmenopausal women $(111 \mathrm{ng} / \mathrm{ml}) ; p$ value $<0.0001$ (Table 1). Circulating concentrations of IGFBP-4 and IGFBP-7 were significantly higher among postmenopausal ( $p$ values $<0.0001$ for both), and IGFBP- 6 was higher among premenopausal women $(p$ value $=0.02$ ) No statistically significant differences by menopausal status were observed for IGFBP-1, IGFBP-2, IGFBP-3, or IGFBP-5 levels. In analyses restricted to participants whose biopsies yielded benign biopsy diagnoses $(86.6 \%$ and $75.7 \%$ of preand postmenopausal participants, respectively), similar patterns of IGF concentrations by menopausal status were observed (Additional file 1: Table S3).

\section{Relationship of circulating IGF measures with select participant characteristics}

Geometric mean concentrations of IGF measures by select participant characteristics are shown in Tables 2 and 3 for pre- and postmenopausal women, respectively.

\section{Age}

Among premenopausal women, IGF-I tended to be inversely associated with age ( $p$ trend $=0.005)$, whereas IGFBP-6 was positively associated with age ( $p$ trend= 0.009) (Table 2). In contrast, none of the IGF measures demonstrated statistically significant trends with age among postmenopausal women (Table 3).

\section{Education}

Among premenopausal women, education was positively associated with IGFBP-5 ( $p$ trend $=0.001$ ) (Table 2). Among postmenopausal women, IGF measures were not significantly associated with education (Table 3 ).

\section{Body mass index}

Among premenopausal women, concentrations of IGFBP-1 and IGFBP-2 decreased with increasing BMI ( $p$ trend $\leq$ $0.0001)$, whereas IGFBP-3 increased with increasing BMI ( $p$ trend $=0.007$ ) (Table 2). Similarly, among postmenopausal women, we also observed inverse associations between IGFBP-1 and IGFBP-2 with BMI ( $p$ trend $\leq 0.0001$ ) (Table $3)$. However, no statistically significant associations with BMI were observed for IGFBP-3. In addition, among postmenopausal women, concentrations of IGFBP-4 and IGFBP-7 were positively associated with BMI ( $p$ trend $=0.005$ and 0.03 , respectively).

\section{Age at first birth}

Among premenopausal women, IGFBP-3 concentration was higher in women with age at first birth $<30$ years compared to women who were nulliparous or whose age at first birth was $\geq 30$ years ( $p$ het $=0.007$ ) (Table 2$)$. None of the remaining IGF measures were significantly associated with age at first birth among pre- or postmenopausal women (Tables 2 and 3).

\section{Cigarette smoking}

Among premenopausal women, IGFBP-5 concentration was lower in current and former as compared to never smokers $(p$ trend $=0.005)$ (Table 2). Though significant heterogeneity in IGFBP-4 $(p$ het $=0.01)$ level was also observed by smoking status, no clear trend was observed. Among postmenopausal women, IGFBP-6 decreased across former and current smoking groups $(p$ trend $=0.02)($ Table 3$)$.

Other participant characteristics such as age at menarche, education, parity, oral contraceptive use, menopausal hormone use, family history of breast cancer in a first-degree relative, age at menopause, breast biopsy prior to enrollment, and biopsy diagnosis were not significantly associated with the IGF measures in either pre- or postmenopausal women.

\section{Relationship of circulating IGF-I and IGFBPs with mammographic density measures}

Age, BMI, and $\mathrm{BMI}^{2}$-adjusted associations of IGF measures with mammographic density measures-percent dense volume/area, absolute dense volume/area, and non-dense volume/area-for pre- and postmenopausal women are presented in Tables 4 and 5, respectively.

\section{Mammographic measures of percent dense volume/area}

Among premenopausal women, IGFBP-2 was positively associated with percent MD-V $(\beta=1.49, p=0.02)$ and percent MD-A $(\beta=1.55, p=0.05)$ (Table 4). IGFBP-4 was inversely associated with percent $\mathrm{MD}-\mathrm{V}(\beta=-7.19$, $p=0.01)$. The ratio of IGF-I:IGFBP-2 was also borderline inversely associated with percent $\mathrm{MD}-\mathrm{V}(\beta=-0.17$, $p$ value $=0.07)$. In contrast, the ratio of IGF-I:IGFBP-3 was borderline positively associated with percent $\mathrm{MD}$ $\mathrm{V}(\beta=5.46, p=0.08)$ before the inclusion of a quadratic term for BMI as an adjustment factor (Additional file 1: Table S4); however, after fully adjusting for BMI, neither IGF-I, IGFBP-3, nor their ratio was associated with MD (Table 4).

Among postmenopausal women, IGFBP-2 was positively associated with percent $\mathrm{MD}-\mathrm{V}(\beta=2.04, p=$ $0.003)$, but other IGF measures were not significantly associated with percent density measures (Table 5). In post hoc analyses, the patterns of association between 


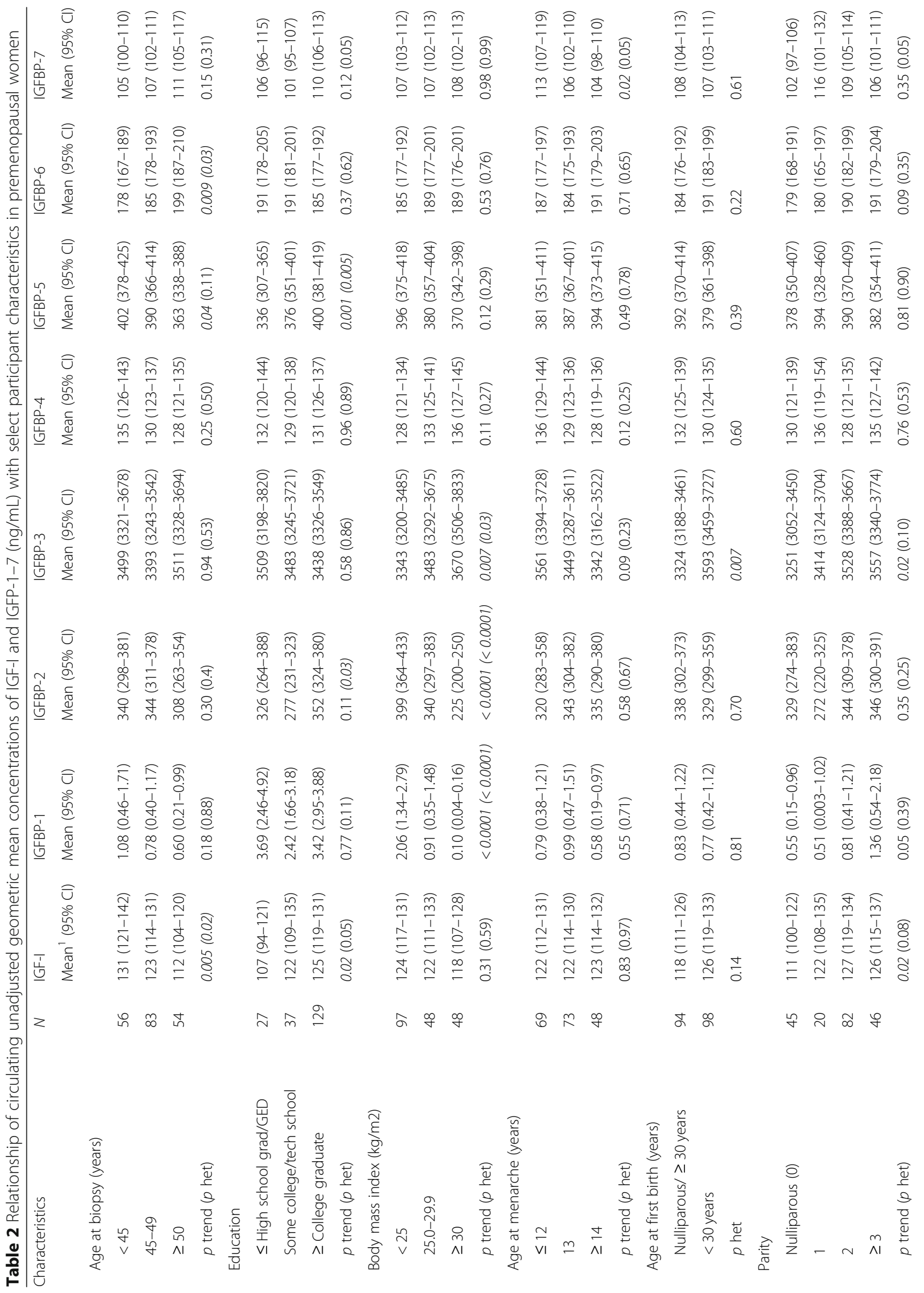




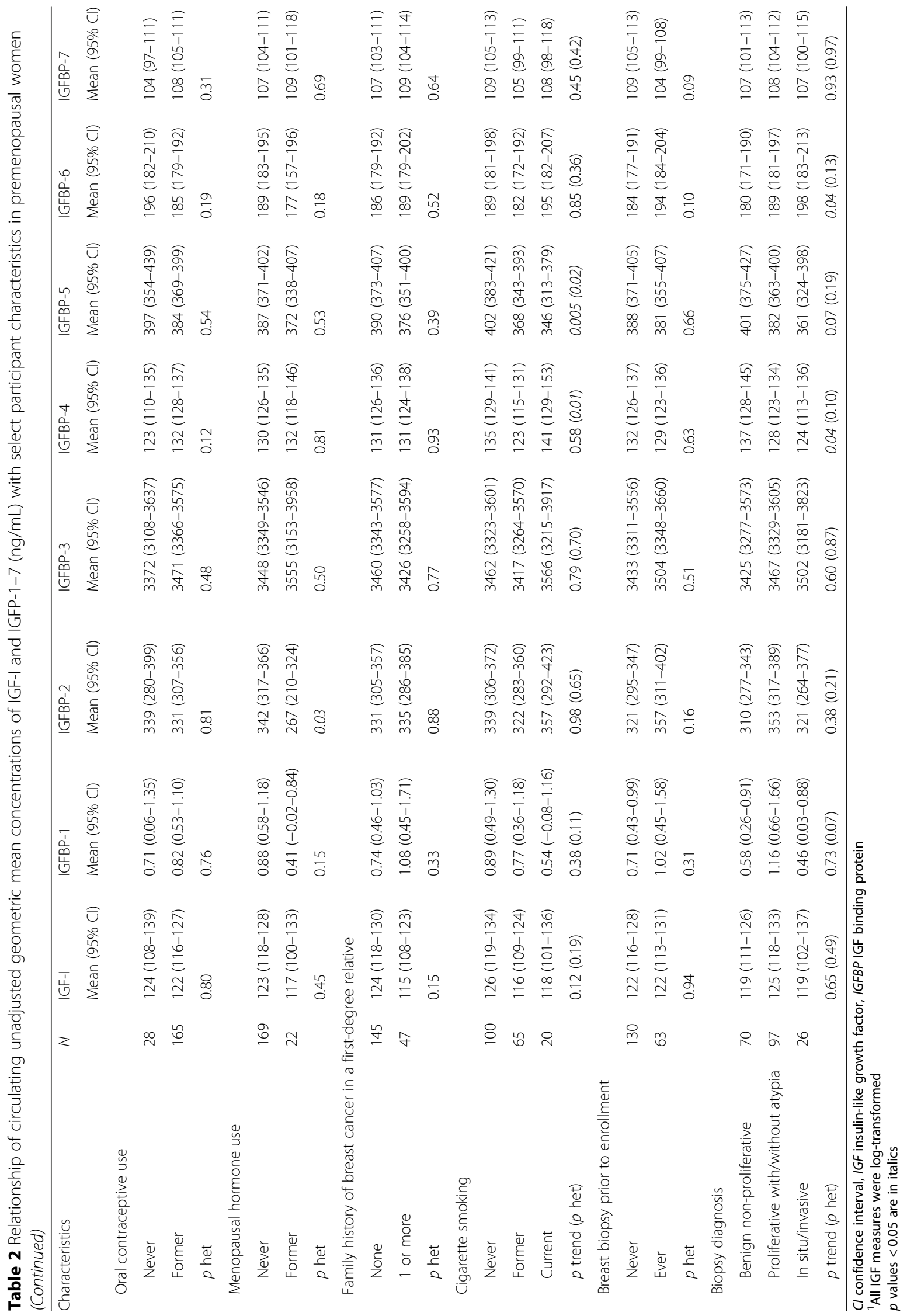




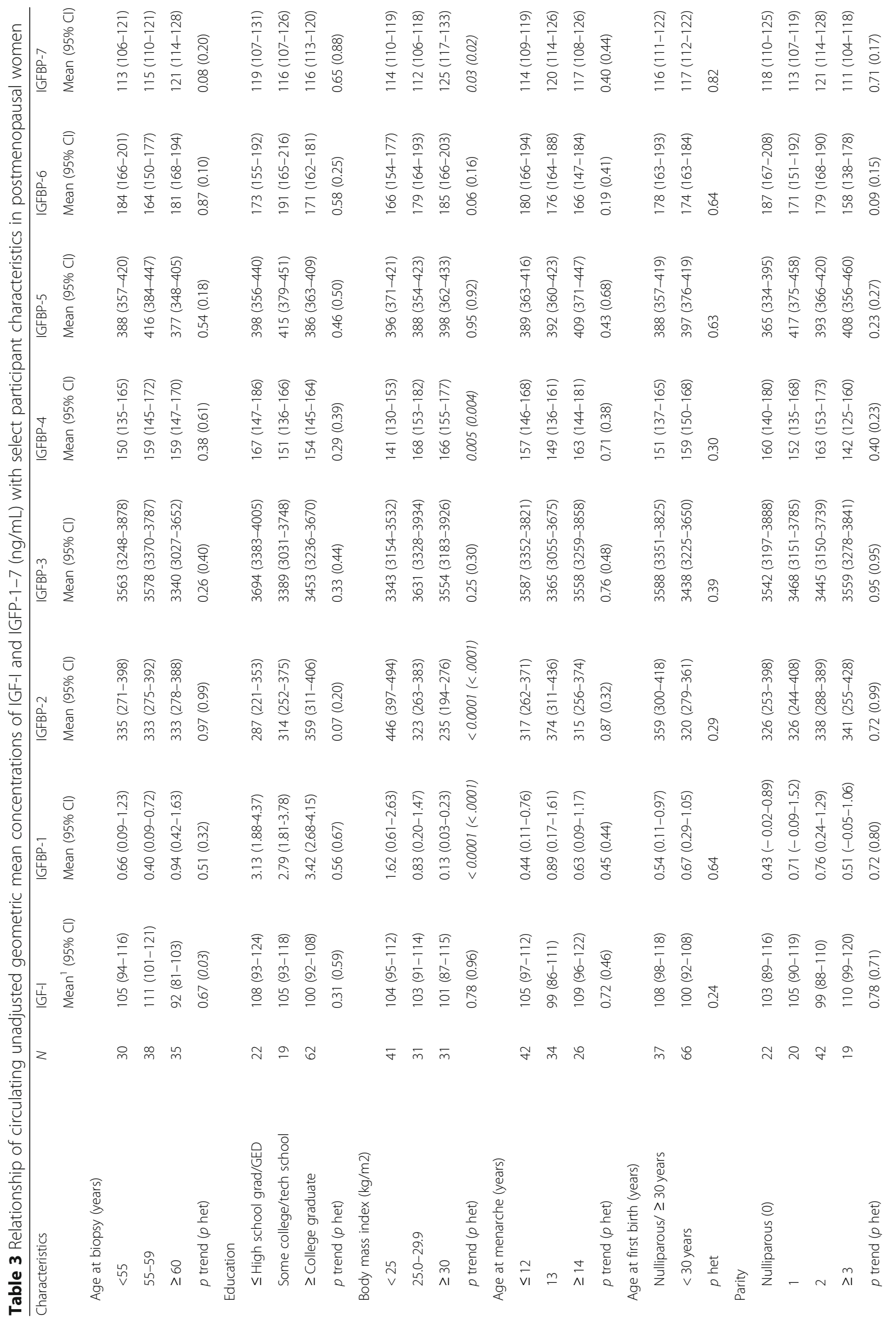




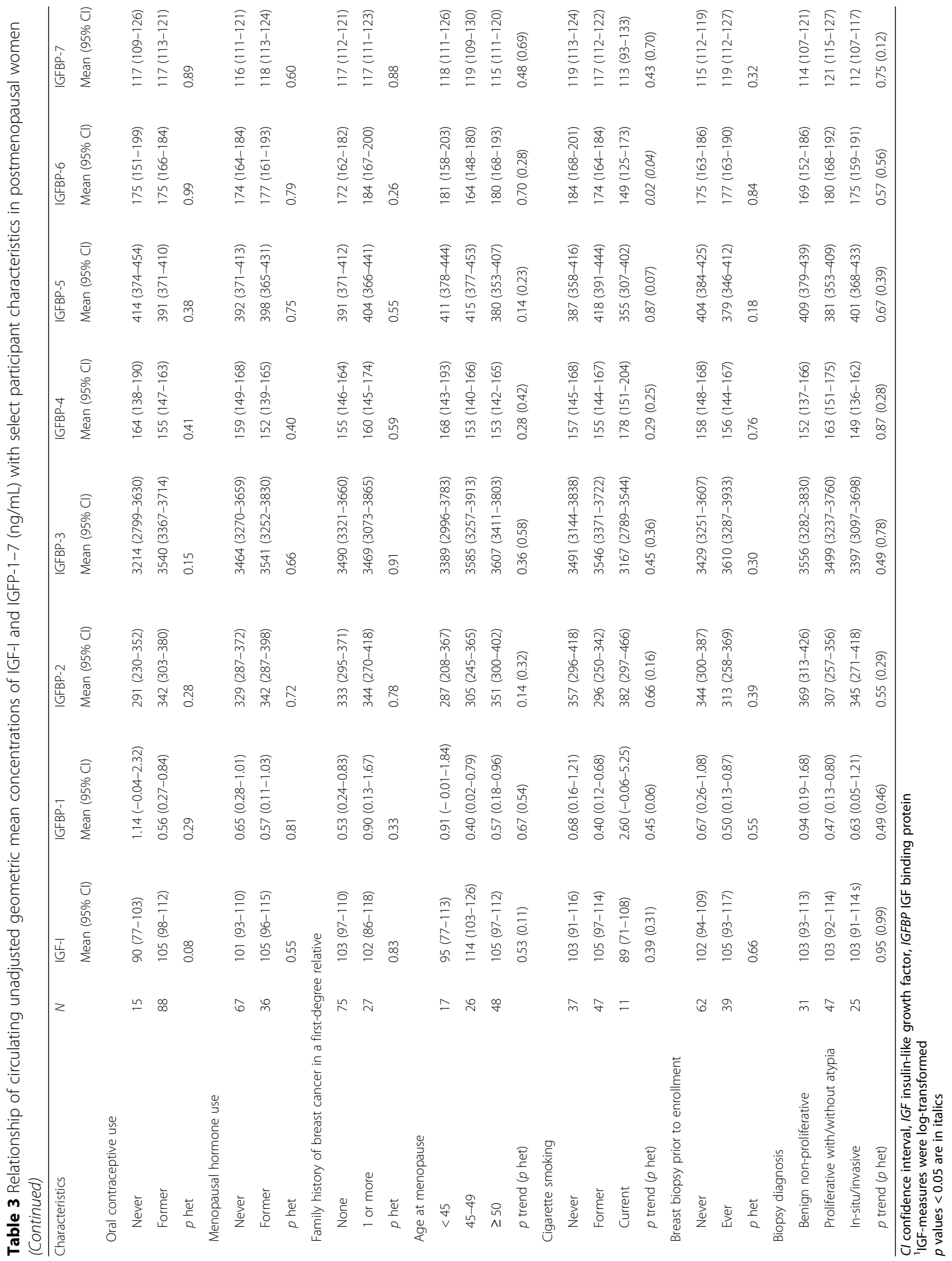


Table 4 Age- and BMl-adjusted ${ }^{2}$ linear regression estimates for associations between IGF measures (pg/mL) and mammographic density measures, premenopausal women $(N=189)$

\begin{tabular}{|c|c|c|c|c|c|c|c|c|c|c|c|c|}
\hline \multirow[t]{2}{*}{ IGF measures } & \multicolumn{2}{|c|}{$\% M D-V^{1}$} & \multicolumn{2}{|c|}{$\%$ MD-A } & \multicolumn{2}{|c|}{ Absolute MD-V } & \multicolumn{2}{|c|}{ Absolute MD-A } & \multicolumn{2}{|c|}{ Non-dense volume } & \multicolumn{2}{|c|}{ Non-dense area } \\
\hline & $\beta$ & $\overline{p^{4}}$ & $\beta$ & $p$ & $\beta$ & $p$ & $\beta$ & $p$ & $\beta$ & $p$ & $\beta$ & $p$ \\
\hline IGF-I & 0.11 & 0.97 & -1.29 & 0.69 & -0.39 & 0.95 & -0.42 & 0.92 & -10.33 & 0.33 & -1.99 & 0.65 \\
\hline |GFBP-1 ${ }^{3}$ & 17.19 & 0.51 & 21.93 & 0.51 & -5.38 & 0.94 & 18.15 & 0.66 & -133.91 & 0.22 & -34.22 & 0.46 \\
\hline IGFBP-2 & 1.49 & 0.02 & 1.55 & 0.05 & 0.35 & 0.83 & 1.48 & 0.13 & -6.56 & 0.01 & -1.74 & 0.11 \\
\hline IGFBP-3 & -0.20 & 0.15 & -0.34 & 0.05 & 0.03 & 0.93 & -0.24 & 0.28 & 0.57 & 0.33 & 0.33 & 0.18 \\
\hline IGFBP-4 & -7.19 & 0.01 & -5.08 & 0.18 & -5.55 & 0.46 & -4.13 & 0.38 & 25.06 & 0.04 & 5.09 & 0.33 \\
\hline IGFBP-5 & -0.50 & 0.50 & 0.37 & 0.69 & -0.37 & 0.84 & 0.45 & 0.70 & 0.48 & 0.88 & -1.21 & 0.35 \\
\hline IGFBP-6 & 0.89 & 0.71 & 2.37 & 0.44 & 9.34 & 0.12 & 5.26 & 0.17 & 1.73 & 0.86 & 0.34 & 0.94 \\
\hline IGFBP-7 & -0.80 & 0.83 & -0.89 & 0.85 & -3.52 & 0.71 & -2.59 & 0.66 & -0.90 & 0.95 & -1.59 & 0.81 \\
\hline |GF-|:|GFBP-1 & $<0.001$ & 0.91 & $<-0.001$ & 0.62 & $<-0.001$ & 0.67 & $<-0.001$ & 0.43 & $<-0.001$ & 0.61 & $<-0.001$ & 0.71 \\
\hline |GF-|:|GFBP-2 & -0.17 & 0.07 & -0.20 & 0.10 & -0.17 & 0.47 & -0.19 & 0.21 & 0.39 & 0.33 & 0.10 & 0.56 \\
\hline |GF-|:|GFBP-3 & 3.31 & 0.28 & 3.29 & 0.40 & 0.003 & 0.99 & 3.27 & 0.50 & -22.38 & 0.08 & -7.38 & 0.17 \\
\hline |GF-1:|GFBP-4 & 0.05 & 0.46 & -0.03 & 0.73 & 0.05 & 0.80 & -0.01 & 0.92 & -0.40 & 0.18 & -0.04 & 0.74 \\
\hline |GF-|:|GFBP-5 & -0.02 & 0.93 & -0.32 & 0.25 & 0.01 & 0.99 & -0.23 & 0.51 & -0.37 & 0.69 & 0.36 & 0.36 \\
\hline |GF-1:|GFBP-6 & -0.03 & 0.83 & -0.19 & 0.29 & -0.37 & 0.29 & -0.27 & 0.23 & -0.64 & 0.28 & -0.11 & 0.64 \\
\hline |GF-1:|GFBP-7 & -0.04 & 0.54 & -0.07 & 0.41 & -0.05 & 0.78 & -0.04 & 0.70 & -0.08 & 0.76 & 0.01 & 0.93 \\
\hline IGF-I:Total IGFBP & 2.99 & 0.46 & 1.35 & 0.80 & 0.20 & 0.98 & 1.76 & 0.78 & -24.14 & 0.16 & -6.35 & 0.37 \\
\hline
\end{tabular}

IGF insulin-like growth factor, IGFBP IGF binding protein, MD-V mammographic density-volume, MD-A MD-area

${ }^{1}$ Mammographic density measures were square-root transformed

${ }^{2}$ All models were adjusted for age, $\mathrm{BMI}$, and $\mathrm{BMI}^{2}$ in the model. Excluded women with $\mathrm{BMI}>45(\mathrm{~N}=4)$

${ }^{3}$ For IGFBP-1, $N=91$ samples were below the lower limit of detection (LLOD) and were reassigned as $1 / 2$ LLOD (0.025)

${ }^{4} p$ values $<0.05$ are in italics

Table 5 Age- and BMl-adjusted linear ${ }^{2}$ regression estimates for associations between IGF measures (pg/mL) and mammographic density measures, postmenopausal women $(N=101)$

\begin{tabular}{|c|c|c|c|c|c|c|c|c|c|c|c|c|}
\hline \multirow[t]{2}{*}{ IGF measures } & \multicolumn{2}{|c|}{$\%{\mathrm{MD}-\mathrm{V}^{1}}^{1}$} & \multicolumn{2}{|c|}{$\%$ MD-A } & \multicolumn{2}{|c|}{ Absolute MD-V } & \multicolumn{2}{|c|}{ Absolute MD-A } & \multicolumn{2}{|c|}{ Non-Dense Volume } & \multicolumn{2}{|c|}{ Non-Dense Area } \\
\hline & $\beta$ & $p^{4}$ & $\beta$ & $p$ & $\beta$ & $p$ & $\beta$ & $p$ & $\beta$ & $p$ & $\beta$ & $p$ \\
\hline |GF-| & -0.55 & 0.89 & 1.97 & 0.70 & -6.57 & 0.49 & 3.10 & 0.64 & -5.95 & 0.77 & -5.26 & 0.48 \\
\hline IGFBP- $1^{3}$ & 50.06 & 0.15 & -49.56 & 0.28 & -84.48 & 0.34 & -77.58 & 0.20 & -418.94 & 0.02 & -8.09 & 0.91 \\
\hline IGFBP-2 & 2.04 & 0.003 & -0.01 & 0.99 & -1.29 & 0.47 & -0.89 & 0.47 & -13.13 & 0.0003 & -1.33 & 0.33 \\
\hline IGFBP-3 & -0.13 & 0.37 & 0.21 & 0.28 & -0.51 & 0.16 & 0.32 & 0.20 & 0.06 & 0.93 & -0.26 & 0.36 \\
\hline IGFBP-4 & -1.72 & 0.55 & -2.22 & 0.56 & 2.74 & 0.70 & -1.03 & 0.84 & 12.02 & 0.43 & 8.42 & 0.13 \\
\hline IGFBP-5 & -0.74 & 0.53 & -0.10 & 0.95 & -0.36 & 0.91 & 0.80 & 0.70 & 2.67 & 0.67 & -0.29 & 0.90 \\
\hline IGFBP-6 & -3.08 & 0.21 & -4.67 & 0.15 & 2.20 & 0.72 & -3.89 & 0.37 & 26.46 & 0.04 & 11.89 & 0.01 \\
\hline IGFBP-7 & 3.56 & 0.53 & -5.21 & 0.49 & 14.32 & 0.32 & -9.46 & 0.34 & -1.77 & 0.95 & 8.43 & 0.45 \\
\hline |GF-|:|GFBP-1 & $<-0.001$ & 0.04 & $<0.001$ & 0.70 & $<-0.001$ & 0.85 & $<0.001$ & 0.33 & 0.0002 & 0.03 & $<0.001$ & 0.75 \\
\hline |GF-|:IGFBP-2 & -0.16 & 0.06 & 0.12 & 0.30 & -0.08 & 0.72 & 0.22 & 0.16 & 0.88 & 0.06 & -0.03 & 0.86 \\
\hline |GF-|:IGFBP-3 & 3.07 & 0.53 & -5.59 & 0.39 & 4.70 & 0.70 & -8.64 & 0.31 & -13.09 & 0.61 & 0.61 & 0.95 \\
\hline |GF-|:|GFBP-4 & 0.01 & 0.96 & 0.14 & 0.41 & -0.14 & 0.67 & 0.19 & 0.38 & -0.11 & 0.87 & -0.25 & 0.31 \\
\hline |GF-I:|GFBP-5 & 0.12 & 0.71 & 0.24 & 0.57 & -0.15 & 0.86 & 0.26 & 0.65 & -0.58 & 0.73 & -0.23 & 0.71 \\
\hline |GF-1:|GFBP-6 & 0.11 & 0.44 & 0.19 & 0.32 & -0.32 & 0.38 & 0.16 & 0.53 & -1.26 & 0.10 & -0.62 & 0.03 \\
\hline |GF-|:|GFBP-7 & -0.07 & 0.54 & 0.11 & 0.45 & -0.20 & 0.45 & 0.22 & 0.24 & 0.11 & 0.84 & -0.11 & 0.59 \\
\hline |GF-I:Total IGFBP & 0.72 & 0.91 & -2.95 & 0.72 & 1.37 & 0.93 & -4.15 & 0.71 & -4.38 & 0.90 & -2.71 & 0.83 \\
\hline
\end{tabular}

IGF insulin-like growth factor, IGFBP IGF binding protein, MD-V mammographic density-volume, MD- $A$ MD-area

${ }^{1}$ Mammographic density measures were square-root transformed

${ }^{2} \mathrm{All}$ models were adjusted for age, $\mathrm{BMI}$, and $\mathrm{BMI}^{2}$ in the model. Excluded women with $\mathrm{BMI}>45(\mathrm{~N}=2)$

${ }^{3}$ For IGFBP-1, $N=91$ samples were below the lower limit of detection (LLOD) and were reassigned as $1 / 2$ LLOD (0.025)

${ }^{4} p$ values $<0.05$ are in italics 
IGFBP-2 and MD measures were consistent in both pre- and postmenopausal women even after adjustment by the most abundant binding protein, IGFBP-3 (data not shown).

Effect modification of the association between IGFBP2 and MD was also considered as a post hoc sensitivity analysis because we observed strong main effects for the relation of both BMI and MD with IGFBP-2, a finding that was not observed for the other IGF measures. Results from BMI-stratified (lean: $<25 \mathrm{~kg} / \mathrm{m}^{2}$; overweight: $25-29.9 \mathrm{~kg} / \mathrm{m}^{2}$; obese: $\left.\geq 30 \mathrm{~kg} / \mathrm{m}^{2}\right)$ analyses are shown in (Table 6). We observed borderline significant positive associations between IGFBP-2 and percent MD-V among premenopausal women who were lean $(\beta=1.32, p=$ $0.07)$ and over-weight $(\beta=2.32, p=0.06)$, but not obese $(\beta=-0.58, p=0.79) ; p$ interaction $=0.57$. Among postmenopausal women, the positive relationships between IGFBP-2 and percent MD-V and MD-A were driven primarily those observed in lean women (MD-V: $\beta=5.32$, $p=0.0002$; MD-A: $\beta=3.24, p=0.07$ ); $p$ interaction $\leq 0.03$.

\section{Mammographic measure of absolute dense and non-dense volume/area}

IGF measures were not associated with absolute MD$\mathrm{V}$ or MD-A in either pre- or postmenopausal women (Tables 4 and 5). However, numerous IGF analytes were associated with non-dense volume and area measures. For example, among premenopausal women, IGFBP-2 was statistically significantly inversely associated with non-dense volume and IGFBP-4 was statistically significantly positively associated with non-dense volume (Table 4). Among postmenopausal women, IGFBP-1 and IGFBP-2 were inversely associated with non-dense volume (Table 5). IGFBP-6 was positively associated with both non-dense volume and area, and IGF-I:IGFBP-1 was positively associated with nondense volume (Table 5). IGF-I:IGFBP-6 was inversely associated with non-dense area (Table 5).

\section{Factor analysis}

Factor analysis of IGF measures revealed 2 independent factors (Additional file 1: Table S6 and Fig. 2). Main contributors to factor 1 were IGFBP-3, IGF-I, IGFBP-1, and IGFBP-2. IGF-I and IGFBP-3 positively contributed to factor 1, and IGFBP-1 and IGFBP-2 negatively contributed to factor 1. IGFBP-4, IGFBP-5, and IGFBP-7 positively contributed to factor 2 . The variance in the IGF measures explained by factor 1 was $53.04 \%, 53.81 \%$, and $55.93 \%$ in overall, premenopausal, and postmenopausal women, respectively. The variance explained by factor 2 was $46.96 \%$, $46.19 \%$, and $44.07 \%$ in overall, premenopausal, and postmenopausal women. The composition of the factors was similar in overall women and each menopausal group even though the levels of IGF measures varied by menopausal status. When we conducted factor analysis using 3 factors, the contribution of each of the IGF proteins to the factors was similar to the model using 2 factors; thus, results are presented for 2 factors.

Table 7 shows the age, BMI, and $\mathrm{BMI}^{2}$-adjusted linear regression model estimates for the association between quintiles of factor 1 and 2 with MD measures. Among premenopausal women, borderline inverse associations of high levels of factor 1 with lower percent MD-V $(\beta=-0.13, p$ value $=0.08)$ and percent MD-A $(\beta=-0.18, p$ value $=0.05)$ were observed. Among postmenopausal women, factor 1 was also inversely associated with percent $\mathrm{MD}-\mathrm{V}(\beta=-0.19$, $p$ value $=0.02$ ). Factor 1 was also positively associated with non-dense volume $(\beta=0.91, p$ value $=0.04)$. In both preand postmenopausal women, factor 2 was not significantly associated with MD measures.

\section{Discussion}

In this study of women undergoing diagnostic breast biopsy, we undertook an analysis of circulating IGF-I and seven of its binding proteins to examine relationships with MD. We did not observe clear associations between

Table 6 Age- and BMI-adjusted linear regression estimates for relationships between IGFBP-2 and \% MD measures in premenopausal and postmenopausal women, stratified by BMI

\begin{tabular}{|c|c|c|c|c|c|c|c|}
\hline \multirow[b]{3}{*}{ MD measure } & \multicolumn{6}{|c|}{ BMl } & \multirow[b]{3}{*}{$p$-int } \\
\hline & \multicolumn{2}{|c|}{$<25 \mathrm{~kg} / \mathrm{m}^{2}(N=97)$} & \multicolumn{2}{|c|}{$25-29.9 \mathrm{~kg} / \mathrm{m}^{2}(N=48)$} & \multicolumn{2}{|c|}{$\geq 30 \mathrm{~kg} / \mathrm{m}^{2}(N=48)$} & \\
\hline & $\beta$ & $p^{1}$ & $\beta$ & $p$ & $\beta$ & $p$ & \\
\hline \multicolumn{8}{|l|}{ Premenopausal women $(N=193)$} \\
\hline$\%$ MD-V & 1.32 & 0.07 & 2.32 & 0.06 & -0.58 & 0.79 & 0.57 \\
\hline \multirow[t]{2}{*}{$\%$ MD-A } & 1.24 & 0.20 & 2.31 & 0.13 & 0.10 & 0.97 & 0.55 \\
\hline & \multicolumn{6}{|c|}{ BMl } & \\
\hline Postmenopausal women ( $N=103)$ & \multicolumn{2}{|c|}{$<25 \mathrm{~kg} / \mathrm{m}^{2}(N=41)$} & \multicolumn{2}{|c|}{$25-29.9 \mathrm{~kg} / \mathrm{m}^{2}(N=31)$} & \multicolumn{2}{|c|}{$\geq 30 \mathrm{~kg} / \mathrm{m}^{2}(N=31)$} & \\
\hline$\%$ MD-V & 5.32 & 0.0002 & 0.81 & 0.24 & -0.29 & 0.85 & 0.0003 \\
\hline$\%$ MD-A & 3.24 & 0.07 & -1.35 & 0.28 & -1.75 & 0.34 & 0.03 \\
\hline
\end{tabular}




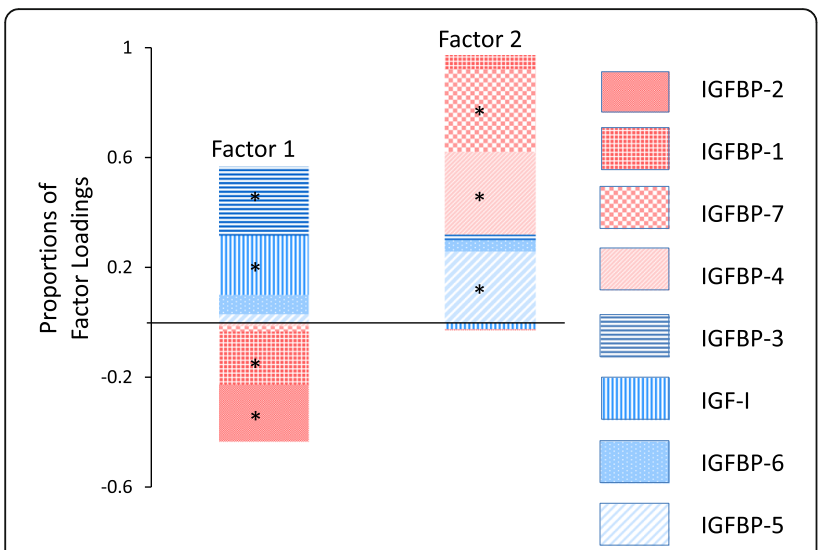

Fig. 2 Results from factor analysis depicting the relative contribution of each insulin-like growth factor (IGF) measure to two independent resulting factors in BREAST Stamp Project participants. IGF, insulinlike growth factor; IGFBP, IGF binding protein; factor 1 was positively correlated with IGF-I and IGFBP-3 and inversely correlated with IGFBP-1 and IGFBP-2; factor 2 was positively correlated with IGFBP-4, IGFBP-5, and IGFBP-7. The proportion of each analyte was determined as the ratio of the factor loading to the sum of absolute values of factor loadings. *IGF measures that were significantly involved in each factor. Factor loading $p<0.05$

IGF-I, IGFBP-3, and MD after BMI adjustment. While prior studies have largely focused on IGF-I and IGFBP3 , we identified novel positive associations between IGFBP-2 and percent MD that withstood rigorous adjustment for BMI, suggesting that IGFBP-2 may play a key role in MD. In concert with in vitro studies demonstrating a dual role of IGFBP-2 on breast tissue (i.e., promoting cell proliferation and inhibiting adipogenesis), our findings suggest that further studies investigating the role of IGFBP-2 in breast tissue composition and the carcinogenic process are warranted.

Prior work indicates that the relation of IGF-I:IGFBP-3 with MD differs by menopausal status, with most studies demonstrating positive associations for premenopausal women, but null associations for postmenopausal women [15-19, 21-24]. We too observed similar associations by menopausal status that were attenuated upon adjusting fully for BMI. In addition to the widely studied IGF proteins (IGF-I and IGFBP-3), this study assessed for the first time the relationship of other IGF binding proteins with MD.

Interestingly, we identified IGFBP-2 as being positively associated with percent MD among all women, a finding which persisted after adjustment for BMI, despite a strong and inverse relation of BMI with both IGFBP2 [26] and percent MD [39]. When we stratified analyses by BMI, we found that the observed positive association between IGFBP-2 and percent MD was most apparent among women with lower BMI, particularly among postmenopausal women. Though we cannot rule out the possibility that the association between IGFBP-2 and percent MD may be due to residual confounding by adiposity, both laboratory and epidemiologic studies have suggested an important role of IGFBP-2 in breast cancer etiology. Prior epidemiologic studies have reported inverse associations between IGFBP-2 and risk of atypical hyperplasia [26] and postmenopausal breast cancer [27]. Other studies have reported null findings for circulating IGFBP-2-associated breast cancer risk relationships [25, 49, 50]. Experimental studies have shown that IGFBP-2 can either inhibit or promote tumorigenesis [30, 51]. IGFBP-2 may inhibit tumorigenesis by inhibiting adipogenesis [52] and promoting apoptosis in an IGFindependent mechanism [53]. Conversely, IGFBP-2 is thought to induce tumorigenesis by promoting cell proliferation and invasion through suppression of PTEN activation and prolonged activity of PI3K $[30,51,54]$. Thus, with IGFBP-2's hypothesized dual effect on breast tissue, it is biologically plausible that the proliferative effect of IGFBP-2 on breast epithelium, along with its inhibition of preadipocyte differentiation into mature adipocytes [55], may be reflected radiologically in elevated breast density.

Table 7 Age- and BMI-adjusted ${ }^{1}$ linear regression estimates for the relation of IGF factors (in quintiles) with mammographic density measures

\begin{tabular}{|c|c|c|c|c|c|c|c|c|c|c|c|c|}
\hline & \multicolumn{2}{|c|}{$\%{\mathrm{MD}-\mathrm{V}^{1}}^{1}$} & \multicolumn{2}{|c|}{$\%$ MD-A } & \multicolumn{2}{|c|}{ Absolute MD-V } & \multicolumn{2}{|c|}{ Absolute MD-A } & \multicolumn{2}{|c|}{ Non-dense volume } & \multicolumn{2}{|c|}{ Non-dense area } \\
\hline & $\beta$ & $p^{3}$ & $\beta$ & $p$ & $\beta$ & $p$ & $\beta$ & $p$ & $\beta$ & $p$ & $\beta$ & $p$ \\
\hline \multicolumn{13}{|c|}{ Premenopausal women } \\
\hline Factor $1^{2}$ & -0.13 & 0.08 & -0.18 & 0.05 & 0.01 & 0.97 & -0.13 & 0.27 & 0.40 & 0.19 & 0.16 & 0.23 \\
\hline Factor 2 & -0.05 & 0.49 & -0.04 & 0.65 & -0.11 & 0.53 & -0.73 & 0.50 & 0.07 & 0.80 & -0.04 & 0.74 \\
\hline \multicolumn{13}{|c|}{ Postmenopausal women } \\
\hline Factor 1 & -0.19 & 0.02 & 0.09 & 0.43 & -0.09 & 0.67 & 0.20 & 0.17 & 0.91 & 0.04 & -0.01 & 0.93 \\
\hline Factor 2 & -0.03 & 0.73 & -0.66 & 0.55 & 0.02 & 0.94 & -0.07 & 0.61 & 0.06 & 0.98 & 0.09 & 0.59 \\
\hline
\end{tabular}

$M D-V$ mammographic density-volume, $M D-A$ MD-area

${ }^{1}$ All models were adjusted for age, $\mathrm{BMI}$, and $\mathrm{BMI}^{2}$ in the model. Excluded women with $\mathrm{BMI}>45$

${ }^{2}$ Factor 1 was positively correlated with IGF-I and IGFBP-3 and inversely correlated with IGFBP-1 and IGFBP-2; factor 2 was positively correlated with IGFBP-4, IGFBP-5, and IGFBP-7. Quintiles' cutpoints for factor 1 and factor 2 were created based on their distributions in premenopausal and postmenopausal women separately ${ }^{3} p$ values $<0.05$ are in italics 
The relationship between IGF proteins and MD measures varied by menopausal status in this study. As several of the IGF proteins as well as the MD measures vary by age and menopausal status, this finding is not necessarily surprising. Further, differences in interactions between circulating hormones, IGF proteins, and the tissue microenvironment [56, 57] may contribute to observed differences by menopausal status. For example, estrogen, a strong breast cancer risk factor, both regulates and is influenced by the IGF family [58]. To better understand the relationship between IGF proteins and $\mathrm{MD}$, future larger studies assessing interrelationships between IGF, hormones, and breast tissue composition in pre-, peri-, and postmenopausal women will be important.

In this study, both volumetric and area mammographic density measures were assessed, and IGF associations with MD-A and MD-V were largely consistent. We have previously shown volumetric and area measures of MD to be highly correlated [39]. We found in multivariate analyses that IGF proteins appeared to be associated with percent MD-V/MD-A, but not absolute dense volume/area measures. Interestingly, we also observed that many of the IGFBPs were inversely associated with non-dense area, suggesting that IGFBPs may also be important correlates of adipose tissue composition in the breast. Indeed, in vitro studies have suggested a role for several IGFBPs in adipogenesis [59]. The role of breast adipose tissue reflected by the radiologic non-dense area in breast cancer development is not well understood [60, 61]. Future mechanistic studies are warranted to study interrelationships between adipocyte biology and endogenous growth factors like IGFBP, with stromal, epithelial, and adipose tissues that are reflected radiologically in $\mathrm{MD}$.

A major strength of this study is that we investigated the relationship of multiple IGFBPs, in addition to the widely studied IGF-I and IGFBP-3, with quantitative, reliable measures of MD. IGF assays used were also highly reliable, with the IGF proteins demonstrating several expected relationships with breast cancer risk factors [14, 62-67]. For example, we found that IGF-I was inversely associated with age, likely due to declines in growth hormone secretion in with aging [63, 66-70]. As expected, IGFBP-2 was inversely associated with $\mathrm{BMI}$ [26]. In contrast to published studies [14, 64, 65, 67], we did not see an association of IGF-I with BMI, though some studies report that only the most extreme BMI levels are associated with the lowest IGF-I, whereas others hypothesize that IGF-I increases with body weight until a threshold is reached and then it triggers the feedback loop suppressing GH secretion. A non-linear U-shaped relationship between BMI and IGF-I has also been reported [71, 72]. We possibly did not see the association due to the low prevalence of obesity in our study population. In examining published literature on serums IGF levels in pre- and postmenopausal women, we found that the levels of IGF-I, IGFBP-3, and their ratio that we observed were within comparable ranges to those reported by the Nurses' Health Study [19]. Likewise, levels of IGFBP-2 in our study were comparable with those previously reported from the nested case-control study within Women's Health Initiative Clinical Trial [26] and within a general community healthcare plan setting [27], lending external validity to our results.

A limitation of this study is that the circulating IGF proteins were measured in a single serum sample, which may not be an adequate representation of future IGF levels within a woman. However, a stability study of IGF-I and IGFBP-3 among premenopausal women in NHS-II demonstrated that the 3-year intraclass correlation coefficient was 0.70 for IGF-I and 0.74 for IGFBP-3 [73]. Thus, a single measurement of IGF-I and BP-3 may be representative for at least 3 years. For other IGF proteins, stability studies should be carried out in the future. In our study, a high proportion of IGFBP-1 $(N=91)$ was below the LLOD, perhaps precluding our ability to detect an association between IGFBP-1 and MD. Though alcohol drinking has been associated with MD [74-78], breast cancer risk [79], and IGF measures [80], information on alcohol consumption was not collected as part of this study. Our study also had a relatively small sample size, particularly upon stratification by menopausal status; larger studies are needed to validate our observed associations between IGF and MD measures. In addition, we measured circulating IGF proteins, and systemic IGFs may differ from those regulating tissue levels [81, 82]. Nevertheless, there is evidence demonstrating that local tissue expression of the IGF proteins may influence the systemic expression of IGF proteins [83, 84].

\section{Conclusions}

We demonstrated a novel positive association between circulating IGFBP-2 and percent MD, particularly among women with lower BMI. These results contribute to the rationale for evaluating relationships between serum IGFs, their multiple binding proteins, and breast cancer risk factors, including $\mathrm{MD}$, to advance our understanding of the IGF proteins in breast cancer etiology.

\section{Additional file}

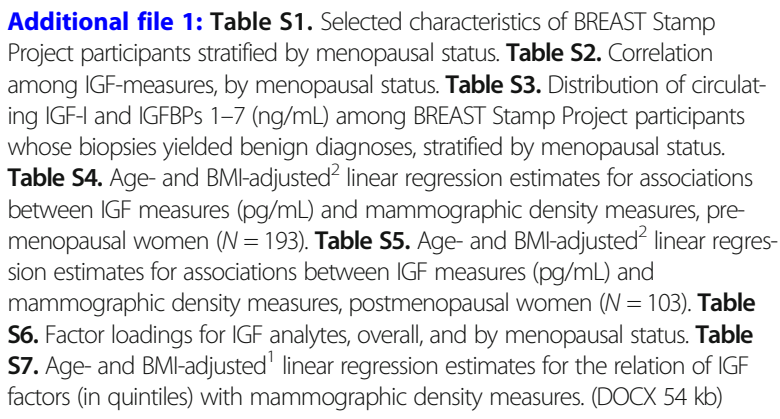

Additional file 1: Table S1. Selected characteristics of BREAST Stamp Project participants stratified by menopausal status. Table S2. Correlation among IGF-measures, by menopausal status. Table S3. Distribution of circulating IGF-I and IGFBPs 1-7 (ng/mL) among BREAST Stamp Project participants whose biopsies yielded benign diagnoses, stratified by menopausal status. Table S4. Age- and BMl-adjusted ${ }^{2}$ linear regression estimates for associations between IGF measures $(\mathrm{pg} / \mathrm{mL})$ and mammographic density measures, premenopausal women ( $N=193$ ). Table S5. Age- and BMl-adjusted ${ }^{2}$ linear regression estimates for associations between IGF measures $(\mathrm{pg} / \mathrm{mL})$ and mammographic density measures, postmenopausal women $(N=103)$. Table S6. Factor loadings for IGF analytes, overall, and by menopausal status. Table S7. Age- and BMl-adjusted ${ }^{1}$ linear regression estimates for the relation of IGF factors (in quintiles) with mammographic density measures. (DOCX 54 kb) 


\section{Abbreviations}

ANOVA: Analysis of variance; BMI: Body mass index; BREAST: Breast Radiology Evaluation and Study of Tissues; CLIA: Chemiluminescence immunoassay; ICC: Intraclass correlations; IGF: Insulin-like growth factor; IGFBPs: Insulin-like growth factor binding proteins; LLOD: Lower limit of detection; MD: Mammographic density; MD-A: Area density measure; MD-V: Volumetric density measure; NCl: National Cancer Institute; SXA: Single X-ray absorptiometry; UCSF: University of California at San Francisco; UVM: University of Vermont

\section{Acknowledgements}

The authors are indebted to the participants in the BREAST Stamp Project for their outstanding cooperation and to the physicians, pathologists, nurses, technologists, and interviewers for their efforts in the field. The authors would like to thank past Research Coordinators at the University of Vermont, Claire Bove, Rachael Chicoine, and Patricia Lutton. The authors are grateful to Janet Lawler-Heaver and Kerry Grace Morrissey from Westat for the study management support and Jane Demuth at Information Management Services for data support and analysis.

\section{Authors' contributions}

GLG and MES were responsible for the conduct and oversight of the $\mathrm{NCl}$ BREAST Stamp Project. MH, HO, RMP, RTF, SF, MM, MP, LAB, MES, and GLG were involved in the analytic concept and design. MH, HO, RTF, SF, MM, MP, $B G, P M V, D W, J S, J W, B F, A P M, S M, S H, L A B, M E S$, and GLG participated in the acquisition of data. MH, HO, RMF, RTF, SF, MM, MP, MES, and GLG contributed to the statistical analyses and participated in the manuscript preparation. All authors participated in the interpretation of results and critical revision of the manuscript for important intellectual content. All authors read and approved the final manuscript.

\section{Funding}

This project was supported in part by the Intramural Research Program of the US National Cancer Institute and a competitive award generated through proceeds from the sale of US breast cancer research postage stamps.

\section{Availability of data and materials}

The dataset generated and/or analyzed during the current study is available from the corresponding author on request.

\section{Ethics approval and consent to participate}

Participants provided written informed consent, which included providing access to medical records and mammographic images. This study was approved by Institutional Review Boards at the University of Vermont and the National Cancer Institute.

\section{Consent for publication}

Not applicable.

\section{Competing interests}

The authors declare that they have no competing interests.

\section{Author details}

${ }^{1}$ National Cancer Institute, National Institutes of Health, Bethesda, MD, USA. ${ }^{2}$ Division of Health Policy and Management, College of Health Sciences, Korea University, Seoul, Republic of Korea. ${ }^{3}$ Royal College of Surgeons in Ireland, Dublin, Ireland. ${ }^{4}$ McGill University, Montreal, QC, Canada. ${ }^{5}$ University of Vermont and Vermont Cancer Center, Burlington, VT, USA. 'University of Hawaii, Honolulu, Hawaii, USA. ${ }^{7}$ Graduate School of Medicine, Hokkaido University, Sapporo, Japan. ${ }^{8}$ University of California San Francisco, San Francisco, CA, USA. ${ }^{9}$ Mayo Clinic, Jacksonville, FL, USA.

Received: 5 February 2019 Accepted: 19 June 2019

Published online: 23 July 2019

\section{References}

1. Martin LJ, Boyd NF. Mammographic density. Potential mechanisms of breast cancer risk associated with mammographic density: hypotheses based on epidemiological evidence. Breast Cancer Res. 2008;10(1):201.
2. McCormack VA, dos Santos Silva I. Breast density and parenchymal patterns as markers of breast cancer risk: a meta-analysis. Cancer Epidemiol Biomark Prev. 2006;15(6):1159-69.

3. Boyd NF, Martin LJ, Yaffe MJ, Minkin S. Mammographic density and breast cancer risk: current understanding and future prospects. Breast Cancer Res. 2011;13(6):223.

4. Huo CW, Chew GL, Britt KL, Ingman WW, Henderson MA, Hopper JL, et al. Mammographic density-a review on the current understanding of its association with breast cancer. Breast Cancer Res Treat. 2014;144(3):479-502.

5. Denduluri SK, Idowu O, Wang Z, Liao Z, Yan Z, Mohammed MK, et al. Insulin-like growth factor (IGF) signaling in tumorigenesis and the development of cancer drug resistance. Genes Dis. 2015;2(1):13-25.

6. Sachdev D, Yee D. The IGF system and breast cancer. Endocr Relat Cancer. 2001;8(3):197-209.

7. Lee AV, Yee D. Role of the IGF system in breast cancer proliferation and progression. In: Manni A, editor. Endocrinology of breast cancer. Totowa, NJ: Humana Press; 1999. p. 187-203.

8. Fang P, Hwa V, Rosenfeld R. IGFBPs and cancer. Novartis Found Symp. 2004; 262:215-30 discussion 30-4, 65-8.

9. Baxter RC. IGF binding proteins in cancer: mechanistic and clinical insights. Nat Rev Cancer. 2014;14(5):329-41.

10. Pollak $M$. The insulin and insulin-like growth factor receptor family in neoplasia: an update. Nat Rev Cancer. 2012;12(3):159-69.

11. Annunziata M, Granata R, Ghigo E. The IGF system. Acta Diabetol. 2011:48(1):1-9.

12. Kasprzak A, Kwasniewski W, Adamek A, Gozdzicka-Jozefiak A. Insulin-like growth factor (IGF) axis in cancerogenesis. Mutat Res Rev Mutat Res. 2017; 772:78-104.

13. Kelley KM, Oh Y, Gargosky SE, Gucev Z, Matsumoto T, Hwa V, et al. Insulinlike growth factor-binding proteins (IGFBPS) and their regulatory dynamics, Int J Biochem Cell Biol. 1996;28(6):619-37.

14. Key TJ, Appleby PN, Reeves GK, Roddam AW. Insulin-like growth factor 1 (IGF1), IGF binding protein 3 (IGFBP3), and breast cancer risk: pooled individual data analysis of 17 prospective studies. Lancet Oncol. 2010;11(6):530-42.

15. Byrne C, Colditz GA, Willett WC, Speizer FE, Pollak M, Hankinson SE. Plasma insulin-like growth factor (IGF) I, IGF-binding protein 3, and mammographic density. Cancer Res. 2000;60(14):3744-8.

16. Diorio C, Pollak M, Byrne C, Masse B, Hebert-Croteau N, Yaffe M, et al. Insulin-like growth factor-1, IGF-binding protein-3, and mammographic breast density. Cancer Epidemiol Biomark Prev. 2005;14(5):1065-73.

17. Boyd NF, Stone J, Martin LJ, Jong R, Fishell E, Yaffe M, et al. The association of breast mitogens with mammographic densities. $\mathrm{Br} J$ Cancer. 2002;87(8):876-82.

18. Maskarinec G, Takata Y, Chen Z, Gram IT, Nagata C, Pagano I, et al. IGF-I and mammographic density in four geographic locations: a pooled analysis. Int J Cancer. 2007;121(8):1786-92.

19. Rice MS, Tworoger SS, Rosner BA, Pollak MN, Hankinson SE, Tamimi RM. Insulin-like growth factor-1, insulin-like growth factor-binding protein-3, growth hormone, and mammographic density in the Nurses' Health Studies. Breast Cancer Res Treat. 2012;136(3):805-12.

20. Rinaldi S, Biessy C, Hernandez M, Lesueur F, dos-Santos-Silva I, Rice MS, et al. Circulating concentrations of insulin-like growth factor-l, insulin-like growth factor-binding protein-3, genetic polymorphisms and mammographic density in premenopausal Mexican women: results from the ESMaestras cohort. Int J Cancer. 2014;134(6):1436-44.

21. Izzo L, Meggiorini ML, Nofroni I, Pala A, De Felice C, Meloni P, et al. Insulinlike growth factor-I (IGF-1), IGF-binding protein-3 (IGFBP-3) and mammographic features. G Chir. 2012;33(5):153-62.

22. dos Santos SI, Johnson N, De Stavola B, Torres-Mejia G, Fletcher O, Allen DS, et al. The insulin-like growth factor system and mammographic features in premenopausal and postmenopausal women. Cancer Epidemiol Biomark Prev. 2006;15(3):449-55.

23. Aiello EJ, Tworoger SS, Yasui Y, Stanczyk FZ, Potter J, Ulrich CM, et al. Associations among circulating sex hormones, insulin-like growth factor, lipids, and mammographic density in postmenopausal women. Cancer Epidemiol Biomark Prev. 2005;14(6):1411-7.

24. Bremnes Y, Ursin G, Bjurstam N, Rinaldi S, Kaaks R, Gram IT. Insulin-like growth factor and mammographic density in postmenopausal Norwegian women. Cancer Epidemiol Biomark Prev. 2007;16(1):57-62.

25. Keinan-Boker L. Bueno De Mesquita HB, Kaaks R, Van Gils CH, Van Noord PA Rinaldi $S$, et al. Circulating levels of insulin-like growth factor I, its binding 
proteins $-1,-2,-3$, C-peptide and risk of postmenopausal breast cancer. Int Cancer. 2003;106(1):90-5.

26. Catsburg C, Gunter MJ, Tinker L, Chlebowski RT, Pollak M, Strickler HD, et al. Serum IGFBP-2 and risk of atypical hyperplasia of the breast. J Cancer Epidemiol. 2015;2015:203284.

27. Krajcik RA, Borofsky ND, Massardo S, Orentreich N. Insulin-like growth factor I (IGF-I), IGF-binding proteins, and breast cancer. Cancer Epidemiology Biomarkers \&amp; Prevention. 2002;11(12):1566-1573.

28. Akkiprik M, Feng Y, Wang H, Chen K, Hu L, Sahin A, et al. Multifunctional roles of insulin-like growth factor binding protein 5 in breast cancer. Breast Cancer Res. 2008:10(4):212.

29. Mita K, Zhang Z, Ando Y, Toyama T, Hamaguchi M, Kobayashi S, et al. Prognostic significance of insulin-like growth factor binding protein (IGFBP)-4 and IGFBP-5 expression in breast cancer. Jpn J Clin Oncol. 2007;37(8):575-82.

30. Beattie J, Hawsawi Y, Alkharobi H, El-Gendy R. IGFBP-2 and -5: important regulators of normal and neoplastic mammary gland physiology. J Cell Commun Signaling. 2015;9(2):151-8

31. Benatar T, Yang W, Amemiya Y, Evdokimova V, Kahn H, Holloway C, et al. IGFBP7 reduces breast tumor growth by induction of senescence and apoptosis pathways. Breast Cancer Res Treat. 2012;133(2):563-73.

32. Marshman E, Green KA, Flint DJ, White A, Streuli CH, Westwood M. Insulinlike growth factor binding protein 5 and apoptosis in mammary epithelial cells. J Cell Sci. 2003;116(Pt 4):675-82.

33. Lochrie JD, Phillips K, Tonner E, Flint DJ, Allan GJ, Price NC, et al. Insulin-like growth factor binding protein (IGFBP)-5 is upregulated during both differentiation and apoptosis in primary cultures of mouse mammary epithelial cells. J Cell Physiol. 2006;207(2):471-9.

34. Allan GJ, Beattie J, Flint DJ. The role of IGFBP-5 in mammary gland development and involution. Domest Anim Endocrinol. 2004;27(3):257-66.

35. Forbes BE, McCarthy $P$, Norton RS. Insulin-like growth factor binding proteins: a structural perspective. Front Endocrinol. 2012;3:38.

36. Firth SM, Baxter RC. Cellular actions of the insulin-like growth factor binding proteins. Endocr Rev. 2002;23(6):824-54.

37. Bach LA. IGF-binding proteins. J Mol Endocrinol. 2018;61(1):T11-t28.

38. Perks CM, Holly JMP. Insulin-like growth factor binding proteins (IGFBPs) in breast cancer. J Mammary Gland Biol Neoplasia. 2000;5(1):75-84.

39. Gierach GL, Geller BM, Shepherd JA, Patel DA, Vacek PM, Weaver DL, et al. Comparison of mammographic density assessed as volumes and areas among women undergoing diagnostic image-guided breast biopsy. Cancer Epidemiol Biomarkers Prev. 2014;23(11):2338-48.

40. Shepherd JA, Kerlikowske K, Ma L, Duewer F, Fan B, Wang J, et al. Volume of mammographic density and risk of breast cancer. Cancer Epidemiol Biomark Prev. 2011;20(7):1473-82

41. Prevrhal S, Shepherd JA, Smith-Bindman R, Cummings SR, Kerlikowske K. Accuracy of mammographic breast density analysis: results of formal operator training. Cancer Epidemiol Biomarkers Prev. 2002;11(11):1389

42. Byng JW, Boyd NF, Fishell E, Jong RA, Yaffe MJ. The quantitative analysis of mammographic densities. Phys Med Biol. 1994;39(10):1629-38.

43. Malkov S, Wang J, Kerlikowske K, Cummings SR, Shepherd JA. Single x-ray absorptiometry method for the quantitative mammographic measure of fibroglandular tissue volume. Med Phys. 2009;36(12):5525-36.

44. Horne HN, Sherman ME, Pfeiffer RM, Figueroa JD, Khodr ZG, Falk RT, et al. Circulating insulin-like growth factor-l, insulin-like growth factor binding protein-3 and terminal duct lobular unit involution of the breast: a crosssectional study of women with benign breast disease. Breast Cancer Res. 2016;18(1):24.

45. Miles FL, Goodman PJ, Tangen C, Torkko KC, Schenk JM, Song X, et al. Interactions of the insulin-like growth factor axis and vitamin $D$ in prostate cancer risk in the prostate cancer prevention trial. Nutrients. 2017;9(4):378.

46. Stolzenberg-Solomon RZ, Limburg P, Pollak M, Taylor PR, Virtamo J, Albanes D. Insulin-like growth factor (IGF)-1, IGF-binding protein-3, and pancreatic cancer in male smokers. Cancer Epidemiol Biomarkers Prev. 2004;13(3):438-44.

47. Bartholomew DJ. Latent variable models and factor analysis. London; New York, N.Y.: Griffin: Oxford University Press; 1987. p 19-81.

48. Kaiser HF, Caffrey J. ALPHA FACTOR ANALYSIS. Psychometrika. 1965;30:1-14.

49. Kaaks R, Lundin E, Manjer J, Rinaldi S, Biessy C, Söderberg S, et al. Prospective study of IGF-I, IGF-binding proteins, and breast cancer risk, in northern and southern Sweden. Cancer Causes Control. 2002;13(4):307-16.

50. Grønbæk H, Flyvbjerg A, Mellemkjær L, Tjønneland A, Christensen J, Toft Sørensen $H$, et al. Serum insulin-like growth factors, insulin-like growth factor binding proteins, and breast cancer risk in postmenopausal women. Cancer Epidemiol Biomarkers Prev. 2004;13(11):1759-64.

51. Pickard A, McCance DJ. IGF-binding protein 2 - oncogene or tumor suppressor? Front Endocrinol. 2015;6:1-6.

52. Wheatcroft SB, Kearney MT, Shah AM, Ezzat VA, Miell JR, Modo M, et al. IGFbinding protein-2 protects against the development of obesity and insulin resistance. Diabetes. 2007;56(2):285-94.

53. Frommer KW, Reichenmiller K, Schutt BS, Hoeflich A, Ranke MB, Dodt G, et al. IGF-independent effects of IGFBP-2 on the human breast cancer cell line Hs578T. Journal of Molecular Endocrinology. 2006;37(1):13.

54. Perks CM, Vernon EG, Rosendahl AH, Tonge D, Holly JM. IGF-II and IGFBP-2 differentially regulate PTEN in human breast cancer cells. Oncogene. 2007; 26(40):5966-72.

55. Yau SW, Russo VC, Clarke IJ, Dunshea FR, Werther GA, Sabin MA. IGFBP-2 inhibits adipogenesis and lipogenesis in human visceral, but not subcutaneous, adipocytes. Int J Obes. 2014;39:770.

56. Kahlert S, Nuedling S, van Eickels M, Vetter H, Meyer R, Grohe C. Estrogen receptor alpha rapidly activates the IGF-1 receptor pathway. J Biol Chem. 2000;275(24):18447-53.

57. Lee AV, Weng CN, Jackson JG, Yee D. Activation of estrogen receptormediated gene transcription by IGF-I in human breast cancer cells. J Endocrinol. 1997;152(1):39-47.

58. Yee $\mathrm{D}$, Lee $\mathrm{AV}$. Crosstalk between the insulin-like growth factors and estrogens in breast cancer. J Mammary Gland Biol Neoplasia. 2000;5(1):107-15.

59. Garten A, Schuster S, Kiess W. The insulin-like growth factors in adipogenesis and obesity. Endocrinol Metab Clin N Am. 2012;41(2):283-95.

60. Pettersson A, Hankinson SE, Willett WC, Lagiou P, Trichopoulos D, Tamimi RM. Nondense mammographic area and risk of breast cancer. Breast Cancer Res. 2011;13(5):R100

61. Bertrand KA, Scott CG, Tamimi RM, Jensen MR, Pankratz VS, Norman AD, et al. Dense and nondense mammographic area and risk of breast cance by age and tumor characteristics. Cancer Epidemiol Biomark Prev. 2015: 24(5):798-809.

62. Bradbury KE, Balkwill A, Tipper SJ, Crowe FL, Reeves GK, Green J, et al. The association of plasma IGF-I with dietary, lifestyle, anthropometric, and early life factors in postmenopausal women. Growth Horm IGF Res. 2015;25(2):90-5.

63. Gram IT, Norat T, Rinaldi S, Dossus L, Lukanova A, Tehard B, et al. Body mass index, waist circumference and waist-hip ratio and serum levels of IGF-I and IGFBP-3 in European women. Int J Obes. 2006;30(11):1623-31.

64. Fowke JH, Matthews CE, Yu H, Cai Q, Cohen S, Buchowski MS, et al. Racial differences in the association between body mass index and serum IGF1, IGF2, and IGFBP3. Endocr Relat Cancer. 2010;17(1):51-60.

65. DeLellis K, Rinaldi S, Kaaks RJ, Kolonel LN, Henderson B, Le Marchand L. Dietary and lifestyle correlates of plasma insulin-like growth factor-I (IGF-I) and IGF binding protein-3 (IGFBP-3): the multiethnic cohort. Cancer Epidemiol Biomarkers Prev. 2004;13(9):1444-51.

66. Lukanova A, Toniolo P, Akhmedkhanov A, Hunt K, Rinaldi S, ZeleniuchJacquotte A, et al. A cross-sectional study of IGF-I determinants in women. Eur J Cancer Prev. 2001;10(5):443-52.

67. Holmes MD, Pollak MN, Hankinson SE. Lifestyle correlates of plasma insulinlike growth factor I and insulin-like growth factor binding protein 3 concentrations. Cancer Epidemiol Biomarkers Prev. 2002;11(9):862-7.

68. Parekh N, Roberts CB, Vadiveloo M, Puvananayagam T, Albu JB, Lu-Yao GL. Lifestyle, anthropometric, and obesity-related physiologic determinants of insulin-like growth factor-1 in the Third National Health and Nutrition Examination Survey (1988-1994). Ann Epidemiol. 2010;20(3):182-93.

69. Landin-Wilhelmsen K, Lundberg PA, Lappas G, Wilhelmsen L. Insulin-like growth factor I levels in healthy adults. Horm Res. 2004;62(Suppl 1):8-16

70. Bartke A. Growth hormone and aging: a challenging controversy. Clin Interv Aging. 2008;3(4):659-65.

71. Schneider HJ, Saller B, Klotsche J, Marz W, Erwa W, Wittchen HU, et al. Opposite associations of age-dependent insulin-like growth factor-l standard deviation scores with nutritional state in normal weight and obese subjects. Eur J Endocrinol. 2006;154(5):699-706.

72. Lukanova A, Soderberg S, Stattin P, Palmqvist R, Lundin E, Biessy C, et al. Nonlinear relationship of insulin-like growth factor (IGF)-I and IGF-I/IGFbinding protein-3 ratio with indices of adiposity and plasma insulin concentrations (Sweden). Cancer Causes Control. 2002;13(6):509-16.

73. Schernhammer ES, Holly JM, Hunter DJ, Pollak MN, Hankinson SE. Insulin-like growth factor-I, its binding proteins (IGFBP-1 and IGFBP-3), and growth 
hormone and breast cancer risk in The Nurses Health Study II. Endocr Relat Cancer. 2006;13(2):583-92.

74. Ziembicki S, Zhu J, Tse E, Martin $\sqcup$, Minkin S, Boyd NF. The association between alcohol consumption and breast density: a systematic review and meta-analysis. Cancer Epidemiol Biomark Prev. 2017;26(2):170-8.

75. McDonald JA, Michels KB, Cohn BA, Flom JD, Tehranifar P, Terry MB. Alcoho intake from early adulthood to midlife and mammographic density. Cancer Causes Control. 2016;27(4):493-502.

76. Flom JD, Ferris JS, Tehranifar P, Terry MB. Alcohol intake over the life course and mammographic density. Breast Cancer Res Treat. 2009;117(3):643-51.

77. Quandt Z, Flom JD, Tehranifar P, Reynolds D, Terry MB, McDonald JA. The association of alcohol consumption with mammographic density in a multiethnic urban population. BMC Cancer. 2015;15:1094.

78. Brand JS, Czene K, Eriksson L, Trinh T, Bhoo-Pathy N, Hall P, et al. Influence of lifestyle factors on mammographic density in postmenopausal women. PLoS One. 2013;8(12):e81876.

79. Hamajima N, Hirose K, Tajima K, Rohan T, Calle EE, Heath CW Jr, et al. Alcohol, tobacco and breast cancer--collaborative reanalysis of individual data from 53 epidemiological studies, including 58,515 women with breast cancer and 95,067 women without the disease. Br J Cancer. 2002;87(11): 1234-45.

80. Barnes BB, Chang-Claude J, Flesch-Janys D, Kinscherf R, Schmidt M, Slanger $T$, et al. Cancer risk factors associated with insulin-like growth factor (IGF)-I and IGF-binding protein-3 levels in healthy women: effect modification by menopausal status. Cancer Causes Control. 2009;20(10):1985-96.

81. Jones Jl, Clemmons DR. Insulin-like growth factors and their binding proteins: biological actions. Endocr Rev. 1995;16(1):3-34.

82. Llanos AA, Brasky TM, Dumitrescu RG, Marian C, Makambi KH, Kallakury BV, et al. Plasma IGF-1 and IGFBP-3 may be imprecise surrogates for breast concentrations: an analysis of healthy women. Breast Cancer Res Treat. 2013;138(2):571-9.

83. Tanaka H, Wakisaka A, Ogasa H, Kawai S, Liang CT. Local and systemic expression of insulin-like growth factor-I (IGF-I) mRNAs in rat after bone marrow ablation. Biochem Biophys Res Commun. 2001;287(5):1157-62.

84. Fu S, Tang H, Liao Y, Xu Q, Liu C, Deng Y, et al. Expression and clinical significance of insulin-like growth factor 1 in lung cancer tissues and perioperative circulation from patients with non-small-cell lung cancer. Current Oncology. 2015;23(1):8.

\section{Publisher's Note}

Springer Nature remains neutral with regard to jurisdictional claims in published maps and institutional affiliations.

Ready to submit your research? Choose BMC and benefit from:

- fast, convenient online submission

- thorough peer review by experienced researchers in your field

- rapid publication on acceptance

- support for research data, including large and complex data types

- gold Open Access which fosters wider collaboration and increased citations

- maximum visibility for your research: over $100 \mathrm{M}$ website views per year

At $\mathrm{BMC}$, research is always in progress.

Learn more biomedcentral.com/submissions 